\title{
ROLA PRZYSŁÓWKÓW WSCHODNIOSŁOWIAŃSKICH W ŚWIADOMOŚCI UŻYTKOWNIKÓW GWAR POLSKICH W OBWODZIE LWOWSKIM W PRZEKROJU POKOLENIOWYM
}

Celem artykułu jest zaprezentowanie zgromadzonego materiału oraz zweryfikowanie na jego podstawie stopnia znajomości zebranych jednostek leksykalnych i ich funkcjonowania w świadomości użytkowników polszczyzny południowokresowej w przekroju pokoleniowym. Podstawę materiałową analizy stanowią wyrazy rodzime i obcego pochodzenia, typowe dla polszczyzny kresowej.

Przywoływany w tym artykule materiał współczesny został pozyskany z następujących miejscowości: Mościsk, Sądowej Wiszni, Rudek, Gródka Jagiellońskiego, Sambora. Są to tereny przygraniczne należące do obwodu lwowskiego. Przed II wojną światową ziemie te należały do Polski. Po wojnie znalazły się w granicach ZSRR, a po 1991 roku należą do Ukrainy. Pozyskany materiał z ekscerpowanych miejscowości pochodzi od informatorów polskiego pochodzenia, którzy posługują się polszczyzną kresową na co dzień w kontaktach domowych i sąsiedzkich. Badania prowadzono w latach 2015-2017. Materiał badawczy został skonfrontowany z zasobem leksykalnym starszych i młodszych użytkowników polszczyzny kresowej, respondentów trzech grup pokoleniowych ${ }^{1}$. Ogółem w badaniach udział wzięło 420 osób, po 140 respondentów z każdego pokolenia ${ }^{2}$. Dane zestawiłam z pozyskanymi w terenie materiałami współczesnymi, zebranymi metodą swobodnej rozmowy.

Tereny te zamieszkuje ludność polska, która obecnie stanowi mniejszość narodową. W Mościskach Polacy stanowią 36\% wszystkich mieszkańców miasta, w Sądowej Wiszni - 25\%, w Gródku Jagiellońskim - 35\%, w Rudkach 25\%, w Samborze 23\%. W obwodzie lwowskim znajduje się największe skupisko Polaków, które zna

${ }^{1}$ Przedziały pokoleniowe podaję według Jerzego Sierociuka: I. urodzeni przed rokiem 1920; II. urodzeni w latach 1921-1945; III. urodzeni w latach 1946-1970; IV. urodzeni w latach 1971-1995; V. urodzeni po 1996 roku (Sierociuk 2003: 134). Tu brałam pod uwagę tylko trzy pokolenia: II. urodzeni w latach 1921-1945; III. urodzeni w latach 1946-1970; IV. urodzeni w latach 1971-1995.

${ }^{2} \mathrm{~W}$ badaniach wzięli udział polskojęzyczni mieszkańcy, nie brano pod uwagę studentów uczących się w Polsce. 
język polski i czynnie posługuje się polszczyzną kresową na co dzień. Język polski jest tu przekazywany z pokolenia na pokolenie. Wszyscy mieszkańcy są bilingwalni, a nawet trójjęzyczni, ponieważ respondenci średniego oraz starszego pokolenia w dobrym stopniu znają również język rosyjski. Polacy, będąc w mniejszości językowej, narażeni są na stały wpływ języka większości, jakim jest język ukraiński. Sytuacja taka prowadzi do interferencji językowej u tych polskich mieszkańców. Ścieranie się wielu elementów językowych prowadzi do znacznych wpływów w systemie językowym zamieszkujących tam Polaków. Polacy, znajdujący się w wielostronnym sąsiedztwie ukraińskim, przejmowali od Ukraińców wiele cech językowych. Wpływy ukraińskie sięgają również gwar polskich na pograniczu kraju, są one najstarsze i najliczniejsze, dotyczą wszystkich działów gramatyki. Ograniczony zakres używania języka polskiego powoduje, że polszczyzna kresowa ma status kodu środowiskowo-rodzinnego. Bliskie pokrewieństwo między tymi językami sprzyja powstawaniu licznych interferencji. Do języka Polaków wprowadzane są cechy języka ukraińskiego, w mniejszym stopniu rosyjskiego, które systemowo występują u wszystkich mówiących. Włączanie tych cech do systemu rodzinnego odbywało się w ciągu wielowiekowego kontaktu z ukraińskim otoczeniem językowym. Pomimo nawet doskonałej wiedzy o poprawnej polszczyźnie nabytej w szkole cechy gwarowe, przejęte z domu rodzinnego, są mocno zakorzenione w świadomości ludzi zamieszkujących na dawnych Kresach południowo-wschodnich.

W zgromadzonym materiale znalazły się leksemy, które są charakterystyczne dla polszczyzny potocznej lub zaliczane we współczesnych słownikach języka polskiego (SJPD, USJP) do przestarzałych, dawnych lub książkowych. Szereg z nich ma również formalne odpowiedniki w języku ukraińskim lub rosyjskim ${ }^{3}$. Do niniejszych badań wzięłam pod uwagę tylko formy gwarowe oraz takie, które w SJPD opatrzone są kwalifikatorami daw., przestarz. lub notowane są w innym znaczeniu. Za Haliną Kurkowską oraz Stanisławem Skorupką za archaizm uznaję wyraz, konstrukcję składniową lub związek frazeologiczny, który wyszedł z użycia. Archaizmy to także wyrazy w formie przestarzałej, które są jeszcze używane, lecz postrzegane jako dawne. Te z kolei nazywa się anachronicznymi (Kurkowska, Skorupka 2001: 66-71).

W celu sprawdzenia geografii wyrazów w gwarach polskich na terenie kraju zweryfikowałam je na podstawie Stownika gwar polskich (dalej SGP) oraz jego kartoteki (KSGP) znajdującej się w IJP PAN w Krakowie. Kilka lat wcześniej na podstawie indeksu KSGP wynotowałam przysłówki gwarowe, poświadczone

\footnotetext{
${ }^{3}$ Przy ustalaniu drogi zapożyczeń służyły mi pomocą polskie słowniki etymologiczne Aleksandra Brücknera, Franciszka Sławskiego, Wiesława Borysia oraz wschodniosłowiańskie: Słownik etymologiczny języka rosyjskiego (Этимологический словарь русского языка) Maksa Vasmera; Stownik etymologiczny języka ukraińskiego (Етимологічний словник української мови) pod red. O.S. Melnyczuka; Etymologiczny słownik języków słowiańskich (Этимологический словарь славянских языков. Праславянский лексический фонд) pod red. O.N. Trubaczeva. Korzystałam również ze Stownika języka polskiego pod red. Witolda Doroszewskiego (dalej SJPD); Stownika języka ukraińskiego (Словник української мови) pod red. I. Biłodida (dalej CYM); Stownika języka ukraińskiego (Словарь украӥнської мови) Borysa Hrinczenki (dalej Hrin.); Słowników języka rosyjskiego (Толковый словарь живого великорусского языка) W. Dala oraz S. Ożegowa, a także Stownika gwar białoruskich (Слоўнік беларускіх гаворак паўночна-заходняй Беларусі і яе пагранічча у пяці тамах) pod red. J.F. Mackiewicz.
} 
w gwarach Małopolski południowo-wschodniej, z uwzględnieniem czynnika pokoleniowego i przedstawiłam ich analizę (Kostecka-Sadowa 2017), do której będę się czasem odwoływać.

Dotychczas przymiotniki czy przysłówki nie były przedmiotem osobnego studium w polszczyźnie południowokresowej. Dlatego moim celem jest wypełnienie tej luki przez przedstawienie wybranych zagadnień leksykalnych na przykładzie materiału z kilku miejscowości obwodu lwowskiego. Uwzględnienie czynnika wieku pozwala poczynić kilka uwag socjolingwistycznych i ukazać wewnętrzne zróżnicowanie badanego języka oraz zmiany w nim zachodzące.

W ostatnich latach pojawiło się wiele opracowań na temat metodologii opisu słowotwórstwa gwarowego i trudności z tym związanych. Jednak brakuje jeszcze syntetycznego ujęcia tej części systemu językowego. W pracach dotyczących słowotwórstwa polszczyzny najszerzej badano rzeczowniki. Słowotwórstwo przymiotników czy przysłówków w literaturze dialektologicznej zajmowało miejsce drugorzędne. W zakresie przymiotników nie ma wiele opracowań dotyczących całego obszaru gwarowego. Szereg prac ze słowotwórstwa i semantyki przymiotnika dotyczy wybranych sufiksów lub kategorii słowotwórczych.

Zjawiska słowotwórcze w badanej polszczyźnie również nie doczekały się dotąd obszerniejszego opracowania. Uwagi o słowotwórstwie rozproszone są w nielicznych artykułach, we fragmentach monografii poszczególnych gwar polskich, pracach o języku pisarzy kresowych.

Wpływ gwar ukraińskich odcisnął swoje piętno na polszczyźnie południowokresowej również w postaci formacji odbiegających od stanu, jaki jest w języku literackim. Większość przysłówków ma strukturę zgodną z polszczyzną ogólną. Zgodność ta bowiem przejawia się nie tylko na płaszczyźnie formalnej, ale też $\mathrm{w}$ identycznych funkcjach znaczeniowych. Z tego względu nie wymagają one bliższego rozpatrzenia. $Z$ drugiej zaś strony są tu formacje odmienne, które omówię w dalszej części artykułu.

Uwagi te odnoszą się również do badanej polszczyzny, która jako polszczyzna pogranicza polsko-ukraińskiego ma część formacji zgodną z gwarami ukraińskimi oraz całym obszarem wschodniosłowiańskim.

Słowiańszczyzna dzieli się na dwa obszary różniące się pod względem stosowania sufiksów -o lub -e. W językach słowiańskich istnieje bardzo żywotna kategoria przysłówków odprzymiotnikowych zakończonych na -o lub -e. Południowa i wschodnia część używa głównie zakończenia -o, zachodnia przede wszystkim -e, język polski zajmuje zaś miejsce pośrednie, gdyż stosuje oba te zakończenia. Polskie przysłówki tworzone są w sposób dość regularny od przymiotników za pomocą formantu -o oraz -e: wesoło, zimno, grubo, bogato, przyjemnie, pewnie.

W gwarach polskich na wschodnim pograniczu kraju przysłówkowy sufiks - $o$, występujący często zamiast polskiego -e, jest ukraińskiego lub białoruskiego (na Mazowszu północnym) pochodzenia, np. czuło, dziwno, fajno, straszno, wcześno (por. Buczyński 1967: 235). Jednakże językoznawcy zgodnie potwierdzają, że w dialektach polskich panuje o wiele mniejsza różnorodność typów przysłówkowych niż w języku ogólnopolskim (Śmiech 1957; Chludzińska 1964). O przysłówkach odprzymiotnikowych na $-o$, $-e$ w mowie mieszkańców dawnych Kresów 
południowo-wschodnich napisałam artykuł, który jest już w druku. Teraz zamierzam napisać o innych jednostkach leksykalnych, zgromadzonych w moich materiałach.

Przechodzę zatem do przeglądu i omówienia zebranych w terenie i przebadanych przeze mnie przysłówków.

Analiza tego materiału pozwala wyodrębnić następujące grupy: przysłówki używane przez wszystkich respondentów (II, III, IV), leksemy znane w mowie średniego i młodszego pokolenia (III, IV) oraz grupa jednostek poświadczona tylko w mowie średniego pokolenia Polaków (III).

$\mathrm{Z}$ odnotowanych 87 przysłówków niemal połowa jest znana wszystkim respondentom reprezentującym trzy pokolenia (II, III, IV). Są to następujące przykłady (42):

bokiem 'nieufnie, niechętnie': bokiem patrzy na mnie; (SGP - Huszcza bial-podl; Kasz LPW I 69); CYM боком; bosonóż 'z gołymi nogami': latym bosonóż si chódzi; (SGP - Aug Wisła XI 779; Radziuszki suw SFPS II 253, 254; suw MAGP VIII m 364 s 56; białos, sokól, suw, aug, biel-podl, Maz pn-wsch MAGP m 365 s 59); SJPD daw.; CYM босоніж; ciut 1. 'nieco, odrobinę': brakuje ciut soli, ciut prozy ni zaszkodzi; (SGP - Mp pn i wsch, Maz); 2. 'zaledwie': ciut si ściemni; (SGP - Maz); CYM чymь pot. 'ledwo'; ciut-ciut 1. 'nieco, odrobinę': dej ciut-ciut soli do smaku; (SGP - Mp wsch, Maz wsch; Kramsk koniń); 2. 'tylko co, zaledwie': przyszed ciut-ciut po tobi; (SGP - opocz, radz-podl PF VI 223); SJPD ciut-ciut pot. 'nieco, odrobinę' z ros. чymb-чymb; dopokiel 'dopóki': bedzi dobrze, dopokiel mnie bedzisz stuchać; (SGP - Kombornia kroś; Blizne brzoz, Hyżne rzesz); dopokil 'dopóki': dopokil nie zaspat, nie dało sie nic zrobić; (SGP - Przędzel niż); SJPD dopóki; CYM dial. допоки; do tych pór 'dotychczas': do tych pór nichtó si ni zglaszol; (SGP - Mp pn); SJPD do tej pory; CYM do mux nip; dotyl 1. 'do tego miejsca; dotąd': zrobiut dotyl, dotyl byto dobrze; (SGP - Budy biel-podl); 2. 'do tego czasu; dopóty': dotyl siedziat $w$ chatupi, aż my nie poszli spać; (SGP - Blizne brzoz; żyw RamŚl 10); SJPD dopóty; CYM domu; dotyla 1. 'do tego miejsca; dotąd': dotyla my doszli; (SGP - Huszcza bial-podl, Mr i Wr SGOWM II 92); 2. 'do tego czasu; dopóty': dotyla my czekali, to i jeszcze troche posiedźmy. dotyla nam bylo dobrze; (SGP - żyw RamŚl 10; n-tar [Orawa] KąśOr 118; Mszana Dolna lim; Mr i Wr SGOWM II 92; byd Pozn VI 315); dowkola 'ze wszystkich stron; wokół': dowkoła taka cisza; (SGP - [pśn] lub, chłm Lub II 14), CYM rzadko довкола; dowpóki 'do czasu, gdy; jeszcze w czasie, gdy': dowpóki si ni ścimnitó, ganiali po łonkach; (SGP - Janki Młode ostroł, Baciki Średnie mław); SJPD dopóty; inaksze 'w inny sposób, nie tak samo, odmiennie': inaksze być nie może; (KSGP - koziel ŚmK1 11; Zabrzeg brzes-śl; miech RŁTN XXII 230; Mr i Wr SGOWM III 37; Tarnopol [Ukr] RŁTN III 60); CYM інакше; jak raz 'akurat, właśnie': jak raz miała iść do was. jak raz si to zaczeło; (KSGP - Mp pn, Maz wsch); CYM якраз 'akurat, właśnie'; kromie 'oprócz': nic nie jadła kromi małej gruszki; (KSGP - Krzemień kras; białos Kudz 158); SJPD daw; ros. кроме; nazad 1. 'z powrotem': ide tam i nazad; (KSGP - oggw); 2. 'w określeniach czasu: wstecz, temu': kilka lat nazad; (KSGP - Mp); SJPD wych. z użycia w gwarach; CYM назад; na czysto 'całkowicie, zupełnie': na czysto o tym zapómniała; (KSGP - Mp, Maz wsch; Ciechocin lip); SJPD wyjść na czysto, puścić kota na czysto; СYM начисто; na szerz 1. 'na szerokość': kupiła materie dwa metry 
na szyrz; (KSGP - Śl, Mp, Kasz); 2. 'na oścież': ótwórzyła dźwi na szyrz i stoi; (KSGP - Śl pn i Wp pd-wsch); SJPD daw.; CYM uup; na zwyż 'na wysokość': na zwyż bedzi ze dwa metry; (KSGP - Mp pd); SJPD daw. na zwyż 'ponad, więcej'; nieuhajnie 'nieporządnie, niechlujnie': nieuchajnie wyglonda, włosy nieuchajnie zaczesane; (KSGP - zam PF V 806); CYM неохайно; niż 'zanim': niż óna przyszła, to zabawa si skończyła. niż ja doszła do roboty, rozpadat si deszcz; (KSGP - Śl, Mp wsch, Maz pn, Pom pd); SJPD spójnik daw.; od dawnia, z dawień dawnia, z dawnia 'od dawna': $z$ dawień dawnia było wiadomo, że tak sie to skończy. od dawnia go już nie widziała. $z$ dawnia do ciebi chodzit; (KSGP - z dawień dawnia Tuch PKFP VII 1 s 100; wej Cen 71, od dawnia, z dawnia Łopiennik Górny kras; Jacnia zam; lub PF IV 190; Trojanów miń-maz; Bilwinowo suw; wys-maz PF IV 899; bial-podl NT II 315); CYM здавен-давна, здавна, здавня, віддавна; pieszki, pieszkom 'na piechotę, pieszo': pieszki tam prendzy zajdziemy, pieszkom przyszli taki kawat drogi; CYM пішки, пішком; poki 'dopóki': poki wszystko było dobrze; (KSGP - Śl); CYM поки; poprzed 'przed, na początku': poprzed tak nie było; (KSGP - Mp pd-zach); CYM noneped 'przedtem' przysłówek; poprzód 1. 'dawniej, przedtem': poprzód wszystko wyglondało inaczej, jak poprzód było; (KSGP - Mp pd i wsch); 2. 'przed': idź poprzód mnie; (KSGP - Mp wsch); SJPD daw. 'przedtem'; CYM nonepedy; potajkom 'potajemnie, tajnie': potajkom my chodzili; (KSGP - Huszcza bial-podl); CYM, Hrin III 375 потайком, потайки; pozajutro 'pojutrze': pozajutro przyjde; (KSGP - Mp wsch, Maz wsch); SJPD przestarz; CYM після завтра; pozawczora 'przedwczoraj': pozawczora byt; (KSGP - Maz wsch); SJPD pozawczoraj, przestarz. pozawczora; СYM після вчора; rano 'wcześnie': nie musisz tak rano wstawać, za rano téż źle, bo jeszcze ciemno bedzi. rano przyszła, toż wszystko zamkniente; (KSGP - Maz wsch, Kramsk koniń; Wtelno byd; Kasz Ram 180); ros., ukr. рано; samo 'akurat, właśnie': samo to chciała i zrobić. samo najlepij bedzi; (KSGP - Maz wsch); CYM само, самe 'akurat'; skróć, skróś 'wszędzie, byle gdzie': zabawki leżo skróć całyj chałupy; (KSGP - Mp pn-wsch, Maz pd-wsch); 2. 'ciągle': skróś stysze to samo; (KSGP - Mp pn-wsch, Maz pd-wsch); SJPD przestarz. skróś; książk. skroś; CYM przysłówek cкpiзs; taki 'jednak, mimo wszystko, przecież': taki uciekła z domu, taki mnie nie postuchała; (KSGP - Mp pn-wsch, Maz pd-wsch K V 380); SJPD reg.; Hrin IV 243, CYM таки; partykuła troszki, troszeczki 'odrobinę, niewiele': troszki tego nasyp i mieszaj, zapominam si troszeczki; (KSGP - Mp, Maz wsch, Wp pn); CYM трошки, трошечки, трішки, трішечки; w doma 'w domu': wdoma tego nie mam, wdoma zapomniała; CYM вдома; widko 'jasno': jeszcze widko na dworze; (KSGP - Kasz LPW III 977); CYM видко; widno 1. 'widocznie, zapewne': widno chciała coś jeszcze powiedzieć, widno tak miało być; (KSGP - Mp pd i wsch, Maz wsch); SJPD daw.; 2. 'widać': Kasi jeszcze nie widno; (KSGP - Mp pd i wsch, Maz wsch); SJPD daw.; CYM видно; wsi, wsia 'wszystek, wszystka': wsia chałupa si spaliła, wsi dzieci tam poszli; CYM zaimek всі, вся; wsio 1. 'zawsze, już': wsio zapominam, wsio było dobrze; (KSGP - Mp, Maz); 2. 'dość': wsio, puść mnie, wsio, koniec roboty na dziś; Hrin IV 354, CYM все, yce, ros. всё; wzad 'z powrotem': idź wzad i przynieść, obróć si wzad; (KSGP - bił Mazur I 119; Zdunek ostroł; koln SkierP II 226; suw PBTN XVIII 36; mrąg PBTN XVIII 3 s 141); CYM dial. взад; zajedno 'ciągle': zajedno mи to gadam; (KSGP - Mp pd i wsch); CYM заодне, 
заодно; za nadro 'za pazuchę': schowej za nadro; (KSGP - Maz); SJPD daw. nadra, zza nadra; CYM надро - rzecz. rzadki; za widka 'póki widać': jeszcze zawidka to zrobisz; CYM завидка 'póki widać'; za widnia 'póki widać': poszedt za widnia i jeszcze go nie ma; (KSGP - Maz wsch); CYM завидна 'póki widać'.

Przedstawiony tu materiał pozwala wysnuć kilka wniosków. Przede wszystkim zwraca uwagę duża liczba wyrazów zapożyczonych w mowie wszystkich badanych respondentów, zwłaszcza też u tych najstarszych osób. Wiele jest jednak wyrazów, które w języku ogólnopolskim już wyszły z użytku, a w słownikach języka polskiego są notowane jako dawne lub przestarzałe. Na przykład w SJPD jako daw. notowane są następujące przykłady: bosonóż, kromie, nazad, na szerz, na zwyż, niż, poprzód, widno, zza nadra; jako przestarz. to: pozajutro, pozawczora, skrós; jako reg. leksem: taki.

Ze zgromadzonego materiału wyłania się grupa wyrazów wspólna gwarom Małopolski i Mazowsza, a głównie ich peryferii wschodnich. Są to następujące przykłady: ciut, inaksze, jak raz, kromie, na czysto, od dawnia, pozajutro, skróć, skróś, taki, troszki, widno, wsio w znaczeniu 'zawsze, już', wzad.

W Małopolsce wschodniej, głównie w kilku miejscowościach, poświadczono następujące wyrazy: do tych pór, dopokiel, dopokil, dotyl oraz dotyla w znaczeniu 'do tego czasu; dopóty', dowkoła, na zwyż, poprzed, poprzód, zajedno. Na Zamojszczyźnie notowano leksem nieuchajnie, a badania poczynione przeze mnie potwierdzają znajomość tego przysłówka przez tamtejszych mieszkańców (zob. Kostecka-Sadowa 2017: 113).

Na wschodnim pograniczu Mazowsza notowano zaś takie leksemy: bokiem, bosonóż, dotyl oraz dotyla w znaczeniu 'do tego miejsca; dotąd', dowpóki, potajkom, pozawczora, rano, samo, za nadro, za widnia. Kilka wyrazów znanych jest w Wielkopolsce i na Kaszubach: na czysto, rano, troszki. W Cieszyńskiem mamy naprociw, na Śląsku poki. Ogólnogwarowe to: nazad, na szerz, niż. Poza tym jest kilka wyrazów nieznanych gwarom polskim, natomiast powszechnie używają ich Polacy zamieszkujący dawne Kresy południowo-wschodnie: pieszki, w doma, widno, wsi, wsia, wsio, za widka.

Jeden leksem jest powszechny w mowie respondentów pokolenia starszego i średniego (II, III), natomiast $\mathrm{w}$ gwarach ukraińskich występuje również w języku osób młodszych: siła 1. 'dużo, wiele': siła tego sie uzbierało, siła tego leży w stodoli; (KSGP - Śl, Mp, Maz, Wp, Pom pd); 2. 'ile': siła tego było nie pamiętam, siła tego wziąć? siła chcesz za to? (KSGP - Śl, Mp, Maz); SJPD daw. dziś gw. 'dużo, wiele, mnóstwo'; CYM сила 'mnóstwo' - rzeczownik. Wszystkim gwarom polskim znany jest przysłówek siła, natomiast SJPD notuje go z kwalifikatorem daw.

Kolejna grupa przykładów jest powszechna w mowie średniego i młodszego pokolenia respondentów (III, IV - 13):

bosikom 'boso': całe lato bosikom chodzili; (SGP - Radziuszki suw SFPS II 253, 254, MAGP VIII m 364 s 56); CYM ukr. босяком, ros. босиком; (na) ugad, uhad 'na chybił trafił': wzięła kilka sztuk naugad; (SGP - białos Kudz 207, 169; suw PKJP II s 44); CYM угадно; ros. на угад; doki 'dopóki': doki bedzie sie uczyć, zawsze bede cie spierać. zostaniesz, doki zechcesz; (SGP - Tarnopol Ukr); CYM доки; narokiem 'umyślnie': tak narokiem powiedziała; SJPD patrzeć narokiem 'patrzeć 
spode łba'; CYM нароком 'umyślnie'; okrom 'oprócz': okrom tego; (KSGP - Śl, Kasz); SJPD przestarz. CYM pot. окрiм; pokil 'dopóki': siedź, pokil nie zawołam; (KSGP - Krak, PF IV 841; białos Kudz 31); CYM pot. покіль, закіль; роśle 'ро': pośle tej awantury nie chce mi sie z nio gadać, pośle tego już nic lepiej nie byto; (KSGP - Huszcza bial-podl; suw, chłm; wys-maz, białos Kudz 182); CYM nісля; ros. nосле; rańsze 'wcześniej, dawniej': ja rańsze do roboty chodziła, jakby ja wiedziała rańsze; ros. paньше; użasno 'okropnie’: użasno śmierdzi, ty użasno schudta; (SGP wej PF V 924); ros., ukr. ужасно; w cypki 'o sposobie siedzenia: w kucki': siedziat w cypki, zwinąt si w cypki; (KSGP - lub PF V 715); ros. в изыnкu; wsiudy 'wszędzie': wsziudy chodzila; (KSGP - Budy biel-podl); CYM всюди; wse 'zawsze': wse ci to mówie, wse tego chciałaś, a teraz nosem kreńcisz; (KSGP - wsze 'zawsze': Mp pd); Hrin IV 354, CYM все, yce; wże, uże 'już': ja wże o tym zapómniała, wże poszła do dоти; (KSGP - bił BartMazur 84); CYM вже; zahałom, zagałem 'ogólnie, razem': zahałom tego wyszło cały worek. weź to zahałom; СYМ загалом.

W tej grupie znalazły się wyrazy, występujące w mowie użytkowników polszczyzny kresowej reprezentujących pokolenie średnie i młodsze. Wiele przykładów poświadczonych jest też w gwarach polskich, ale najczęściej w pojedynczych miejscowościach. Na Mazowszu wschodnim notowane są: bosikom, na ugad, pośle, wsiudy. Na Lubelszczyźnie poświadczono przysłówek $w$ cypki, w Biłgorajskiem: wże, w południowej Małopolsce: wse, przysłówek znany w Małopolsce i na Mazowszu to pokil; na Śląsku i Kaszubach: okrom. Oprócz tych wymienionych przykładów w badanej polszczyźnie zanotowałam takie przykłady: doki, narokiem (w SJPD jest patrzeć narokiem), rańsze, użasno, zahałom. SJPD notuje okrom jako przestarz.

Liczną grupą pochodzenia wschodniosłowiańskiego są wyrazy występujące w mowie Polaków średniego pokolenia. Są to leksemy głównie wschodniosłowiańskiego pochodzenia (III - 31):

bieżkiem 'szybko, prędko': bieżkiem pyńdź du sónsiadki; (SGP - gar Maz III 222; Białystok Maz V 274); CYM бігом, біжком; gołkiem 1. 'na bosą stopę': gołkiem założyt gumaki i poszedt w pole; (SGP - Wilków kiel, iłż, konec, bus, piń, rad, raw-maz, skier, grój AWK III 377); 2. 'bez przykrycia, bez schowania gdzieś': gółkiem nosisz tyn pularys; (SGP - białos Kudz 146; Aug K II 101; pog Grój i Pias SKJ IV 364; Janki Młode ostroł; Kramsk koniń); hoda, hody 'trudno’: hodi było wytrzymać z tym dzieckim, hody przejść koło tego obojętnie; (SGP - Mp wsch); Hrin I 298; Dal I 903; CYM pot. zodi; krom 'oprócz': krom ciebie nie mam już nikogo, krom niego nichtó nie przyszedt; (KSGP - Śl, n-tar, Sławatycze włod; Mr i Wr, Kasz Ram 80); SJPD przestarz.; CYM крім; krugiem 'ciągle': śmieci krugiem leżeli, krugiem pytat ludzi; (KSGP - Kocudza bił); krugom 'dookoła': krugom było biało; (KSGP - Kadzidło ostroł; suw PKJP II 2s 47/547; białos Kudz 158); ros. кругом; CYM кругом 'wszędzie, ciągle, całkowicie'- przysłówek; 'naobkoło'- przyimek; kudy 'gdzie tam': kudy mu się bedzie chciało robić za darmo! kudy on ci powie! (KSGP - Wysocze os-maz; białos Kudz 159; Huszcza bial-podl; suw PKPJ II 2 s 47); CYM кyдu; na bezrok 'przez rok': na bezrok wystarczy; (KSGP - Śl, Mp, Kuj); CYM безрiк; nahodom 'wkrótce': nahodom przyszedt; CYM нагодом; napered 'zawczasu': trza było to napered powiedzieć; CYM нaneped; naproci, naprociw 1. 'po przeciwnej stronie': stała naprociw ciebi, naproci tyj chatupy; 2. 'przeciwko': zrobiła to 
naprociw mnie; (KSGP - naprociw Wisła ciesz, Ciesz SCiesz II 201); CYM нanpomu, напротив; na bosiaka 'boso': na bosiaka chodzili cate lato; (SGP - Budy biel-podl; sokół MAGP VIII m 364 s 56); SJPD na bosaka; CYM ukr. босяком, ros. босиком; na bosiny 'boso': na bosiny tam nie chódź; (SGP - Turów radz-podl PF VI 219) brus. na bosiny; na przejmy 'zmieniając się': na przejmy my to robili, tak troche byłó lżej; Hrin III 119 - перейма'; CYM на перейми; niecharasznie 'źle, niedobrze': niecharasznie zrobiła, aż hody patrzeć; (KSGP - Hyżne rzesz); nieskoro 'nieprędko, późno’: nieskoro wrócit, nieskoro go zobaczysz; (KSGP - Ś1, Mp pd); SJPD rzadki; CYM нескоро; poprzódy 'dawniej, przedtem': jak było poprzódy, poprzódy całkim inaczej wygladato; (KSGP - Mp wsch); CYM nonepedy; prychapcy 'szybko i byle jak’: założyła chustke prychapcy i poleciata; (KSGP - Ukr); CYM npuxanui, прихапцем; siudy 'tu': siudy pójdziesz, siudy skreńć; CYM сюдu; skoro 'prędko': leć skoro, zawieź skoro to do babci; (KSGP - Mp); SJPD przestarz., CYM скоро 'szybko'; skróć, skróś 'przez, z powodu': to si stałó skróś ciebi, skróś tyj nogi nie moge chodzić; (KSGP - Mp); SJPD przestarz. skróś; ksiązk. skroś; CYM przyimek скрізь; smytko 'prędko, żwawo'; (KSGP - radz-podl PF VI 263); szwydko 'ts': szwydko leć do mamy; Hrin IV 489, CYM швидко; strimhołow 'szybko': strimhołow peńdził do szkoły, strimhołow mi to załatw; CYM стрімголов; takoj 'jednak, mimo wszystko, przecież': takoj do mnie nie przyszła, takoj zapomniała; ros. maкoü; wsiak 'przecież': wsiak tak chciałaś, wsiak o to chodziło; CYM всяк; wsiako 'różnie': wsiako w tym życiu bywa; CYM всяко; wsieniutko 'wszystko': wsieniutko zasiała, wsieniutko poszło z dymem; (KSGP - Budy biel-podl); CYM всенький; z małeczku 'od małego': z małeczku ja chodziła krowy paść; (KSGP - Mr i Wr SGOWM IV 97); CYM малечку; z naroku 'umyślnie, specjalnie': z naroku tak powiedziat, z naroku tak zróbiła; (KSGP - Degucie suw; suw PBTN XVIII 37; Maz pn-wsch SGOWM IV 265; Mr MPKJ III 477); CYM нароком 'umyślnie, specjalnie'; ze wsiem 'całkowicie': ze wsiem zapómniała; (KSGP - Kuj II 279); CYM зовсім; ros. совсем.

Przedstawione przykłady wskazują wyraźnie na pochodzenie wschodniosłowiańskie. Wiele $\mathrm{z}$ nich jest notowanych również w gwarach polskich. Na Mazowszu wschodnim KSGP podaje następujące przykłady: bieżkiem, krugiem, kudy ${ }^{5}$, na bosiaka, na beznoge, smytko, wsieniutko, z małeczku, z naroku; leksem na bosiny wskazuje na białoruskie pochodzenie. W Małopolsce poświadczone są przysłówki hoda, hody, poprzódy, skoro, w Rzeszowskiem - niecharasznie. Wspólne w Małopolsce i na Mazowszu: gołkiem oraz krom. Ostatni leksem notowano też na Kaszubach. W Małopolsce oraz na Śląsku zapisane są leksemy: na bezrok, niekoro. Poza tym w mowie Polaków średniego pokolenia odnotowałam wyrazy: nahodom, napered, na przejmy, pryhapcy, szwydko, strimhołow, takoj oraz wsiak 'przecież', wsiako 'różnie'. SJPD jako przestarz. notuje przysłówek krom.

Jeden przysłówek jest używany w mowie Polaków reprezentujących tylko młodsze pokolenie (IV): na blank 'z pewnością, na sto procent': Na błank ón dzisiej przyjdzi, nie denerwuj si. Un zapomni o tym na błank; (SGP - 'zupełnie, do cna':

\footnotetext{
${ }^{4}$ Pożyczka z XVII wieku u Szymonowica (Hrabec 1949: 88).

${ }^{5}$ Przykład ten znany jest również w południowo-wschodniej Małopolsce z wyraźnym nacechowaniem emocjonalnym (Kostecka-Sadowa 2017: 109).
} 
Uograli mie dziś na blank Sękowa gor; Mp pd); CYM бланк 'blankiet'. Występuje on w mowie potocznej również Ukraińców $\mathrm{z}$ tegoż przedziału pokoleniowego.

Przytoczone przykłady pokazują, że ogromna liczba zgromadzonego słownictwa to wyrazy wschodniosłowiańskie. Bilingwizm oraz stałe kontakty z ludnością ukraińską sprzyjają licznym wpływom i zapożyczeniom w mowie badanych Polaków. Porównanie tych leksemów z KSGP pokazuje, że wiele wyrazów notowanych jest też w gwarach polskich na terenie kraju: na Mazowszu czy w Małopolsce, sięgają one nawet na Kaszuby, Wielkopolskę czy Śląsk.

$\mathrm{Z}$ ponad 80 przysłówków wyekscerpowanych $\mathrm{w}$ terenie, skonfrontowanych z badanymi mieszkańcami, a potem porównanych z KSGP, prawie połowa występuje w mowie najstarszych użytkowników polszczyzny kresowej (są to 42 leksemy). Pokolenie młodsze potwierdziło używanie 57 omawianych wyrazów. Natomiast reprezentanci pokolenia średniego w swoim czynnym zasobie leksykalnym posługują się 87 jednostkami leksykalnymi. To głównie oni są nosicielami zapożyczeń wschodniosłowiańskich, a zarazem też wyrazów, które w słownikach języka polskiego są już traktowane jako dawne czy przestarzałe.

Przeprowadzone przeze mnie badania pokazują, że z ponad 80 wyrazów o proweniencji wschodniosłowiańskiej najwięcej występuje tylko na samym Mazowszu, są to 24 przykłady. Wiele z nich ogranicza się tylko do wschodnich obszarów kraju, np.: na beznoge, na bosiaka, na uhad, z naroku, za widnia, bokiem, gołkiem, krugom, kudy, potajkom, samo, smytko, wsiudy.

Z zebranych przysłówków - aż 19 występuje w Małopolsce, głównie na wschodnim pograniczu, np.: do tych pór, na blank, na zwyż, w cypki, dowkoła, hody, krugiem, nazad 'w określeniach czasu: wstecz, temu', niecharaznie, skoro, zajedno.

W całym wschodnim pasie kraju znanych jest 16 przykładów - zarówno w gwarach mazowieckich, jak i małopolskich poświadczone są: ciut, inaksze, jakraz, krom, pokil, pośle, wsio.

Kilka wyrazów jest również poświadczonych w Wielkopolsce (6): na czysto, na szerz 'na oścież', ze wsiem, na bezrok, gotkiem 'bez przykrycia, bez schowania gdzieś', rano; na Kaszubach poświadczono 8 leksemów: bokiem, krom, okrom, od dawnia, z dawnia, rano, użasno, widko, na szerz; na Śląsku znanych jest 7 przykładów: na bezrok, inaksze, naprociw 'przeciwko', na szerz, nieskoro, okrom, poki.

Wyrazy ogólnogwarowe to: nazad, na szerz, niz, siła, troszki.

$\mathrm{Na}$ samych dawnych południowo-wschodnich Kresach wyrazów jest 19: na przejmy, za widka, doki, nahodom, napered, naprociw, narokiem, pieszki, pryhapcy, rańsze, siudy, strimhołow, takoj, w doma, wsi, wsiak, wsio, wsiako, zahałom.

SJPD notuje z kwalifikatorem daw. następujące przykłady: bosonóż, kromie, nazad, na szerz, na zwyż, niż, poprzód, siła, widno, zza nadra; jako przestarz.: krom, okrom, pozajutro, pozawczora, skróś; jako reg. leksem: taki.

Przeprowadzona analiza pokazuje, że większość jednostek leksykalnych jest o proweniencji wschodniosłowiańskiej. Badani respondenci nie zawsze są świadomi, że używane przez nich przysłówki mają proweniencję ruską. Spełniają one ważną rolę, gdyż oddają dokładne intencje mówiącego.

Nie wszystkie wymienione wyżej przysłówki zostały zapożyczone wprost z gwar ukraińskich. Niektóre z nich mogą być zapożyczone z ukraińskiego za 
pośrednictwem polskiego języka literackiego, niektóre mogą być archaizmami zachowanymi pod wpływem języka ukraińskiego. Nie zawsze da się przeprowadzić dokładne analizy genetyczne. Interesującą kwestią jest przystosowywanie wyrazów ukraińskich do rodzimego systemu fonetycznego.

Liczba zebranych wyrazów pokazuje, że gwary na pograniczu kraju ulegały znacznym wpływom wschodniosłowiańskim. Szczególnie mocno oddziaływały na nie gwary ukraińskie, mniej gwary białoruskie na północnym wschodzie kraju. Najmniejszy jest wpływ języka rosyjskiego, który był początkowo językiem zaborców, a jego nowsze kontakty z gwarami polskimi są świeże i krótkotrwałe.

\section{Wykaz skrótów nazw powiatów}

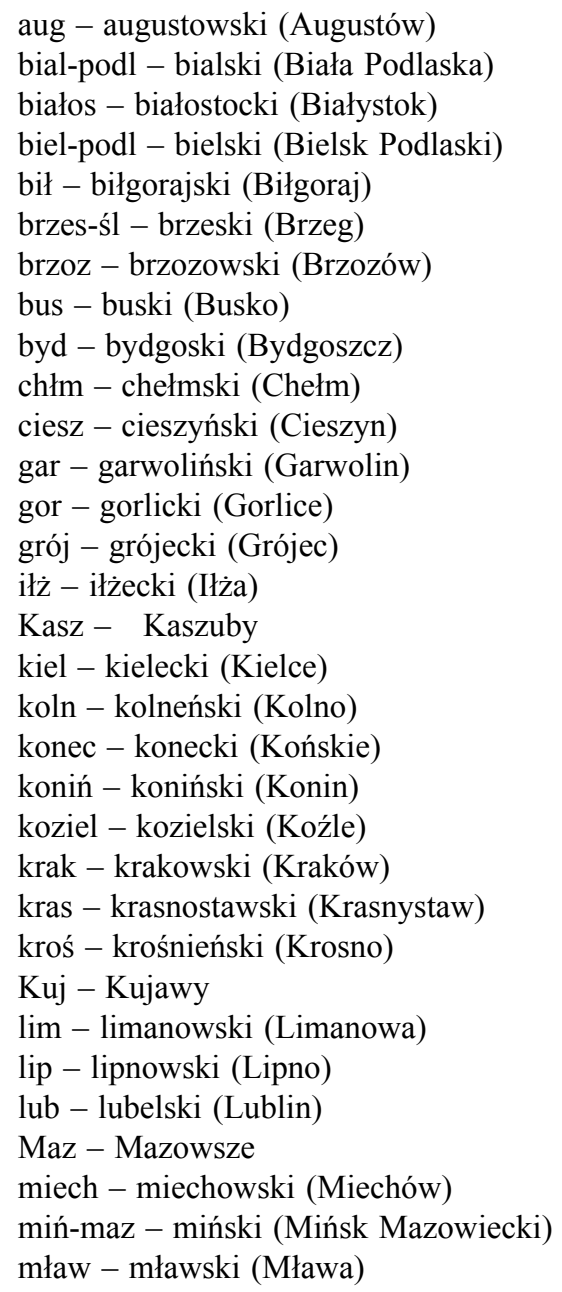

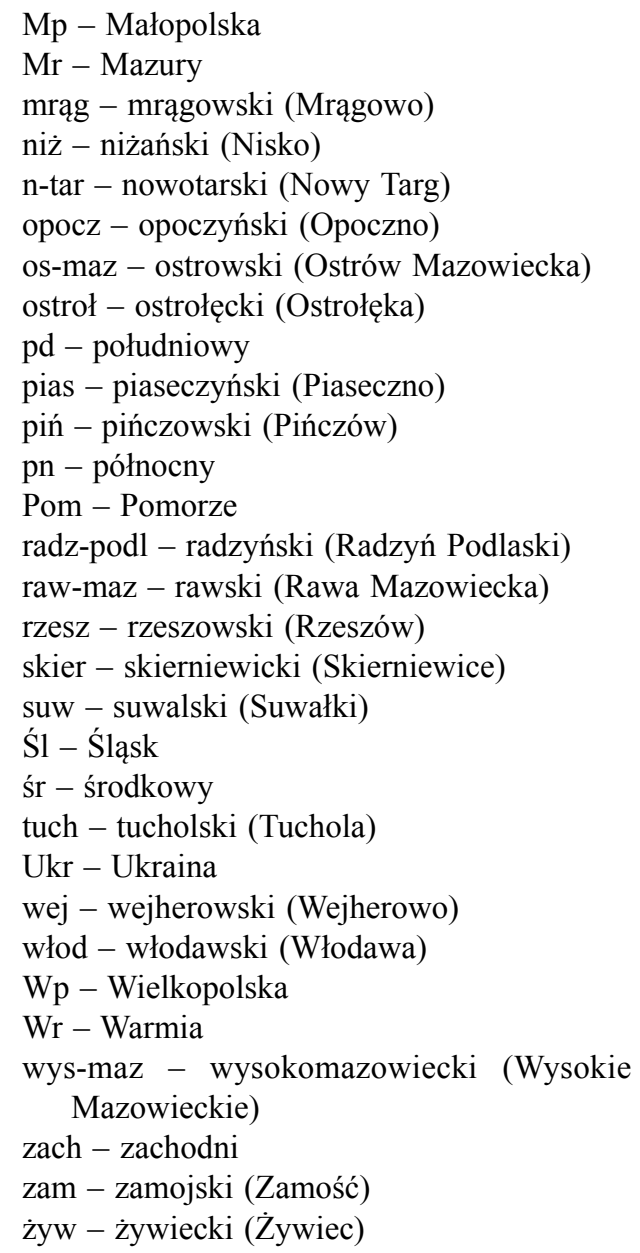




\section{Wykaz źródel materiału gwarowego}

AWK - K. Dejna, Atlas gwarowy województwa kieleckiego, z. 1-6, Łódź 1962-1968.

BartMazur - J. Bartmiński, J. Mazur, Teksty gwarowe z Lubelszczyzny, Zakład Narodowy im. Ossolińskich, Wrocław 1978.

Cen 71 - F. Cenowa, Zarés do grammatikj Kašebsko-Slovjinskje Mòvé, Poznań 1879.

K - J. Karłowicz, Słownik gwar polskich, t. 1-6, Kraków 1900-1911.

KąśOr - J. Kąś, Interferencja leksykalna stownictwa gwarowego i ogólnopolskiego (na przykładzie gwar orawskich), Kraków 1994.

Kudz - D. K. Rembiszewska, Stownik dialektu knyszyńskiego Czesława Kudzinowskiego, Łomżyńskie Towarzystwo Naukowe im. Wagów, Łomża 2007.

Kuj - O. Kolberg, Lud. Jego zwyczaje, sposób życia, mowa, podania, przysłowia, obrzędy, gusła, zabawy, pieśni, muzyka i tańce, Seria III, IV. Kujawy, cz. 1-2, Warszawa 1867.

LPW - F. Lorentz, F. Hinze, Pomoranisches Wörterbuch, t. 1-5, Berlin 1958-1983.

Lub - O. Kolberg, Lud. Jego zwyczaje, sposób życia, mowa, podania, przysłowia, obrzędy, gusła, zabawy, pieśni, muzyka i tańce, Seria XVI, XVII. Lubelskie, cz. 1-2, Kraków 1883-1884.

MAGP - Mały atlas gwar polskich, oprac. przez Pracownię Atlasu i Słownika Gwar Polskich Zakładu Językoznawstwa PAN w Krakowie, t. 1-2 pod kier. K. Nitscha, t. 3-13 pod kier. M. Karasia, Wrocław 1957-1970.

Maz - O. Kolberg, Mazowsze. Obraz etnograficzny, t. 1-5, Kraków 1885-1890.

Mazur - J. Mazur, Gwary ludowe okolic Biłgoraja, cz. 1. Fonologia, cz. 2. Fleksja, Wrocław-Warszawa-Kraków-Gdańsk 1976, 1978.

MPKJ III 397-487 - K. Nitsch, Dialekty polskie Prus Wschodnich, „Materiały i Prace Komisji Językowej Akademii Umiejętności” w Krakowie, 1-8, Kraków 1907.

NT II - K. Nitsch, Wybór polskich tekstów gwarowych, Wydanie drugie zmienione przez autora, Warszawa 1960.

PBTN XVIII 7-94 - Teksty gwarowe z Białostocczyzny z komentarzem językowym. Praca zbiorowa pod redakcją A. Obrębskiej-Jabłońskiej, „Prace Białostockiego Towarzystwa Naukowego", Warszawa 1972.

PF IV 173-279 - R. Lubicz [Hieronim Łopaciński], Przyczynki do nowego słownika języka polskiego, „Prace Filologiczne”, t. 6, Warszawa 1893, s. 173-279.

PF IV 795-904 - Z. Gloger, Stownik gwary ludowej w okr. Tykocińskim, „Prace Filologiczne”, t. 4, Warszawa 1893, s. 795-904.

PF V 681-976 - H. Łopaciński, Przyczynki do nowego słownika języka polskiego, „Prace Filologiczne", t. 5, Warszawa 1899, s. 681-976.

PF VI 187-276 - W. Pracki, O mowie wsi Turowa, „Prace Filologiczne”, t. 6, Warszawa 1907, s. $187-276$.

PKJP II 2 - T. Zdancewicz, Wpływy białoruskie w polskich gwarach pod Sejnami, „Prace Komisji Językoznawczej Poznańskiego Towarzystwa Przyjaciół Nauk”, Poznań 1966.

PKFP VII 1 - L. Zabrocki, Gwara Borów Tucholskich (Szkic historyczno-genetyczny), „Prace Komisji Filologicznej Poznańskiego Towarzystwa Przyjaciół Nauk”, Poznań 1934.

Pozn - O. Kolberg, Lud. Jego zwyczaje, sposób życia, mowa, podania, przystowia, obrzędy, gusła, zabawy, pieśni, muzyka i tańce, Seria IX-XV. Poznańskie, t. 1-7, Kraków 1875-1882 .

Ram - S. Ramułt, Słownik języka pomorskiego, czyli kaszubskiego, Kraków 1893.

RamŚl - S. Ramułt, Gwara ślemieńska, t. 1. Stownik. Do druku przygotował i wstępem opatrzył Edward Klich, Poznań 1930.

RŁTN III 31-76 - S. Hrabec, O polskiej gwarze wsi Duliby w b. powiecie buczackim, „Rozprawy Komisji Językowej Łódzkiego Towarzystwa Naukowego", Łódź 1955. 
RŁTN XXII 135-268 - K. Dejna, Stownictwo ludowe z terenu bylych województw kieleckiego i łódzkiego (E-J), „Rozprawy Komisji Językowej Łódzkiego Towarzystwa Naukowego”, Łódź 1976.

S - B. Sychta, Stownik gwar kaszubskich na tle kultury ludowej, t. 1: A-G, t. 2: H-L, t. 3: Ł-O, t. 4: P-̌̌n, t. 5: S-T, t. 6: U-Ž, t. 7: Suplement, Zakład Narodowy im. Ossolińskich, Wrocław-Warszawa-Kraków (-Gdańsk) 1967, 1968, 1969, 1970, 1972, 1973, 1976.

SCiesz - J. Krop, J. Twardzik, J. Pilch, J. Wronicz, Słownik gwarowy Śląska Cieszyńskiego, pod red. Jadwigi Wronicz, Wisła-Ustroń 1995.

SFPS II 247-269 - T. Zdancewicz, Osobliwości akcentowe w gwarze wsi Radziuszki pod Sejnami, „Studia z Filologii Polskiej i Słowiańskiej”, t. 2, Warszawa 1957, s. 247-269.

SGOWM - Stownik gwar Ostródzkiego, Warmii i Mazur. Zeszyt próbny, t. 1: A-Ć, pod red. Z. Stamirowskiej, Wrocław-Warszawa-Kraków-Gdańsk-Łódź 1987; t. 2: D-G, pod red. Z. Stamirowskiej, Wrocław-Warszawa-Kraków 1991; t. 3: H-K, pod red. Z.Stamirowskiej i H. Perzowej, Warszawa-Kraków 1993; t. 4: L-N, pod red. H. Perzowej i D. Kołodziejczykowej, Warszawa-Kraków 2002; t. 5: O-Ó, pod red. H. Perzowej i D. Kołodziejczykowej, Warszawa-Kraków 2006.

SGP - Stownik gwar polskich, oprac. przez Zakład Dialektologii Instytutu Języka Polskiego PAN w Krakowie, t. 1 pod kier. M. Karasia, t. 2-5 pod kier. J. Reichana, t. 6-7 pod kier. J. Okoniowej, Kraków 1982-2007.

SkierP - W. Skierkowski, Puszcza kurpiowska w pieśni, cz. 1, 2, Płock 1928, 1929-1934.

SKJ IV 362-373 - W. Matlakowski, Zbiór wyrazów ludowych dawnej ziemi czerskiej, „Sprawozdania Komisji Językowej Akademii Umiejętności w Krakowie”, t. 1-5, Kraków 1891.

ŚmK1 - S. Śmiełowski, Kleklimanki. Opowieści ludowe ze Ślaska Opolskiego, Katowice 1967.

Wisła XI 771-783 - A. Osipowicz, Lecznictwo ludowe. Nazwy ludowe niektórych chorób, $z$ wymienieniem środków, używanych po wsiach na ich leczenie w dawnym Augustowskiem, „Wisła. Miesięcznik geograficzno-etnograficzny”, t. 11, Warszawa 1897.

\section{Bibliografia}

Bal J., 1974, Formacje przysłówkowe z sufiksalnym j $i$ k typu dzisiaj, wczoraj, dzisiak, tamok $w$ historii $i$ dialektach języka polskiego, Zakład Narodowy im. Ossolińskich, Wydawnictwo PAN, Wrocław-Warszawa-Kraków-Gdańsk.

Biernacka M., 1966, Wsie drobnoszlacheckie na Mazowszu i Podlasiu, Wrocław-WarszawaKraków, Zakład Narodowy im. Ossolińskich.

Buczyński M., 1967, Wschodniostowiańskie wplywy językowe w gwarze wsi Huszcza powiat Biała Podlaska, „Annales Universitatis Mariae Curie-Skłodowska. Sectio F, Nauki Filozoficzne i Humanistyczne" 22, s. 223-256.

Chludzińska J., 1964, Uwagi o przystówkach w gwarach Warmii i Mazur, „Prace Filologiczne” 18,3 , s. $133-142$.

Cyran W., 1967, Przystówki polskie. Budowa słowotwórcza, Zakład Narodowy im. Ossolińskich, Łódź.

Dobrzycki S., 1907, Przysłówki na -o $i$-ě od przymiotników w języku staropolskim na podstawie zabytków wieku XIV i XV, „Prace Filologiczne” 6, 1, s. 56-150.

Hrabec S., 1949, Elementy kresowe w języku niektórych pisarzy polskich XVI i XVII w., Towarzystwo Naukowe w Toruniu, Toruń.

Jodłowski S., 1949, O przysłówkach, partykułach i im pokrewnych częściach mowy, „Język Polski" t. 29, s. 97-106. 
Kostecka-Sadowa A., 2013, Wybrane tendencje słowotwórcze w polszczyźnie południowokresowej na przykładzie Mościsk i okolic, „Socjolingwistyka” 27, s. 153-161.

Kostecka-Sadowa A., 2017, Funkcjonowanie zapożyczeń wschodniosłowiańskich w świadomości użytkowników gwar polskich na przykładzie przysłówków, „Rozprawy Komisji Językowej Łódzkiego Towarzystwa Naukowego" 64, s. 103-122.

Kurek H., 2006, Zróżnicowanie polszczyzny wiejskiej a czynniki pozajęzykowe, „Gwary dziś. 3. Wewnętrzne zróżnicowanie języka wsi”, red. J. Sierociuk, Poznań, s. 53-57.

Kurkowska H., Skorupka S., 2001, Stylistyka polska. Zarys, PWN, Warszawa.

Lindertówna B., Kilka uwag o archaizmach językowych spotykanych na terenie miasta Lublina, „Język Polski” 47, s. 72.

Miodunka W., 1970, Imiesłowy przysłówkowe w dialektach języka polskiego, „Zeszyty Naukowe UJ” 229, „Prace Językoznawcze” 29, s. 95-117.

Mirowicz A., 1947, Przysłówki przy liczebnikach, zaimkach i rzeczownikach, „Język Polski” 27, s. $166-168$.

Obrębska A., 1934, Studia nad stowiańskimi przysłówkami, 1. Polskie dopiero i formacje pokrewne, Kraków.

Otrębski J., 1928, Polskie formacje przysłówkowe typu wczoraj, „Język Polski” 14, s. 170-173 .

Otrębski J., 1956, Z dziejów wyrazów polskich, 16, kiej, teraz, „Język Polski” 46, s. 97-99.

Safarewicz J., 1948, O funkcji przysłówków w języku polskim, „Język Polski” 28, s. 47-50.

Sierociuk J., 2003, Założenia metodologiczne badań języka wsi, „Poznańskie Spotkania Językoznawcze” 11, red. Z. Krążyńska i Z. Zagórski, Poznań, s. 131-136.

Szober S., 1933, Jeszcze o przysłówkach określających rzeczowniki, „Poradnik Językowy”, s. $69-71$.

Śmiech W., 1957, O polskich przysłówkach odprzymiotnikowych na -o, -e, „Rozprawy Komisji Językowej Łódzkiego Towarzystwa Naukowego" 5, s. 61-76.

Zdancewicz T., 1966, Wpływy białoruskie w polskich gwarach pod Sejnami, Poznańskie Towarzystwo Przyjaciół Nauk, Poznań.

\section{Słowniki}

Boryś - W. Boryś, Słownik etymologiczny języka polskiego, Kraków 2005.

Brückner - A. Brückner, Stownik etymologiczny języka polskiego, wyd. 5, Warszawa 1989.

Dal - W.I. Dal, Tołkowyj słowa'żywogo wielikorusskogo jazyka, t. 1-4, Sankt-Pieterburg-Moskwa 1903-1909.

ESBM - H.A. Cychun (red.), Etymałahiczny stounik biełaruskaj mowy, t. 1-13, Minsk 1988-2010 .

ESSJa - O.N. Trubaczew (red.), Etymołohiczeskij słowar' sławianskich jazykow. Prasławianskij leksyczeskij fond, t. 1-, Moskwa 1974-.

ESUM - O.S. Melnyczuk (red.), Etymołohicznyj słownyk ukrajins'koji mowy, t. 1-6, Kyjiw 1982-2011.

Hrinczenko - B.D. Hrinczenko, Stowar' ukrajins 'koji mowy, t. 1-4, Kyjiw 1907-1909.

Ożegow - S.I. Ożegow (red.), N.J. Szwedowa, Tołkowyj słowar' russkogo jazyka, Moskwa 1992.

SBH - J.F. Mackiewicz (red.), Stounik biełaruskich haworak paunoczna-zachodniaj Biełarusi i jaje pahraniczcza u piaci tamach, t. 1-5, Minsk 1979-1986.

SJPD - W. Doroszewski (red.), Stownik języka polskiego, t. 1-11, Warszawa 1958-1968.

Sławski - F. Sławski, Słownik etymologiczny języka polskiego, t. 1-5, Kraków 1952-1982. 
Słpsł. - F. Sławski (red.), Słownik prasłowiański, t. 1-8, Wrocław 1974-2001.

SUM - I.K. Biłodid (red.), Słownyk ukrajins 'koji mowy, t. 1-11, Kyjiw 1970-1980, http:/lcorp. ulif.org.ua/dictua/ (dostęp: 10.02.2107).

USJP - S. Dubisz (red.), Uniwersalny słownik języka polskiego, t. I-IV, Warszawa 2003.

Vasmer - M. Vasmer, Etymołohiczeskij słowar' russkoho jazyka, thum. i uzup. O.N. Trubaczewa, t. 1-4, Moskwa 1986-1987.

\title{
ANNA KOSTECKA-SADOWA
}

\section{The role of Eastern Slavic adverbs as realised by users of Polish subdialects in the Lvov district across generations}

\begin{abstract}
Summary
This article presents and verifies material embedded in the awareness of users of Polish spoken in the southern part of Eastern Borderlands of the country across generations. The close relation between Polish and Ukrainian languages is conducive to the emergence of numerous interferences. Inclusion of Ukrainian features into the Polish system took place in the course of many centuries of contacts with speakers of the Ukrainian language.

Ukrainian subdialects have left their mark on the Polish language in the southern part of Eastern Borderlands also in formations which deviate from the literary language. In the Polish language under scrutiny - the language spoken on the Polish-Ukrainian borderland, some formations follow Ukrainian subdialects and the entire Eastern Slavic area. A majority of adverbs have a structure compliant with the general Polish language. However, there are also different formations, typical of borderland subdialects.
\end{abstract}

Keywords: Polish spoken in southern part of Eastern Borderlands, adverbs, Ukrainian subdialect, borrowings 